Original Article

\title{
Reproductive performance of sows inseminated with diluted semen treated with homeopathic medicine
}

\author{
Francisco Rafael Martins Soto ${ }^{1,3}$, Erlete Rosalina Vuaden², \\ Cideli de Paula Coelho ${ }^{3}$, Leoni Villano Bonaminn${ }^{4}$, Sérgio Santos de Azevedo ${ }^{5}$, \\ Nilson Roberti Benites ${ }^{3}$, José Antônio Visintin³ ${ }^{3}$ Flavia Regina Oliveira de \\ Barros $^{3}$, Marcelo Demarchi Goissis ${ }^{3}$, Mayra Elena Ortiz D’Ávila Assumpção ${ }^{3}$, \\ Mariana Groke Marques ${ }^{3}$.
}

1 Ouro Preto, Swine Farm, Ibiúna, São Paulo, Brazil.

2 M Cassab, Animal Technology, São Paulo, Brazil.

3 University of São Paulo, College of Veterinary Medicine and Zootechny, Brazil.

4 Paulista University, College of Veterinary Medicine, São Paulo, Brazil.

5 Academic Unity of Veterinary Medicine of Federal University of Campina Grande, Patos Campus, Paraíba, Brazil.

\begin{abstract}
Aims: this study sought to assess the reproductive performance of sows inseminated with sperm treated with homeopathic medicines. Materials and methods: the semen of 2 sexually mature boars age 18 months Pietrain and Duroc cross-bred with similar genetic and reproductive performance were chosen, as well as 125 sows. Sixteen samples of semen were collected and standardized through semen evaluation. Three homeopathic preparations and a placebo (control) were tested on the sperm (n=31/32 per group): Avena sativa $6 \mathrm{cH}$, Pulsatilla nigricans $6 \mathrm{cH}$ and Avena sativa $6 \mathrm{cH}+$ Pulsatilla nigricans $6 \mathrm{cH}$. Sows were inseminated 3 times with the same estrous diagnostic procedures. Results: there was significant difference $(\mathrm{p}<0.05)$ between Avena sativa $6 \mathrm{cH}$ and the other 3 groups regarding the return to estrus and parturition rate. There was no significant difference among the groups regarding the number of newborn piglets. Conclusion: these data suggest that homeopathic preparation Avena sativa may be used directly on sperm cells to improve the parturition rate in technified swine farms.
\end{abstract}

Key Words: swine, reproductive performance, semen, homeopathy, blind-controlled study.

\section{Introduction}

Artificial insemination is used to increase reproductive efficiency and productivity in the production of swine [1]. Although this technology is already established, there is a constant need to improve the reproductive zootechnical results of herds when using this procedure [2]. The demand for new researches and alternative products to improve the quality of swine semen and to decrease costs [3] is growing in middle- and large-sized swine farms worldwide [4]. 
Different protocols have been applied to semen to improve its quality and consequently to improve the parturition rate and the number of newborns [5, 6, 7]. Although there are few studies on the effect of homeopathic medicine directly applied to the semen in order to stimulate the activity of the sperm cells and the fecundity rate in swine herds [8], this seems to be a promising way to improve reproductive results. Among the homeopathic preparations that can be used for reproduction in human beings and domestic animals Avena sativa and Pulsatilla nigricans are mentioned in the literature. Avena sativa, prepared from oat, has been described as influencing different metabolic processes, mainly the ones related to reproduction, through an action on the male reproductive system and a positive effect on the sperm cells [9]. Pulsatilla nigricans or Anemona pratensis belongs to the Ranunculaceae family and grows in windy slopes of Europe. It provokes benefic effects in the reproductive system of domestic animals, on both male and female organs, improving fertility and consequently also reproduction [10]. The positive effect of Avena sativa and/on Pulsatilla nigricans on the fecundity of human beings and domestic animals as already been reported [11, 12].

The aim of this study was to test the effect of both homeopathic remedies separated and in combination on sperm cells of boars in order to evaluate the reproductive performance of sows inseminated with that semen.

\section{Materials and Methods}

\subsection{Experimental method}

The experiment was developed during 7 months between April $20^{\text {th }}$ and November $20^{\text {th }}, 2008$, at the artificial insemination facility of a commercial swine farm with 200 sows at Ibiúna, São Paulo, Brazil. The semen of 2 mature boars aged 18 months was used. Boars were Pietrain and Duroc cross-bred, with similar genetic and reproductive performance, progeny BP $450 \AA$, originated from the same sows and boars production farm (table 1). Animals were housed in individual stalls with heat control and fed with $16 \%$ crude protein of ground corn, soy dust, corn germ, vitamin and mineral supplementation without antibiotics.

Table 1- Reproductive performance expected for the progeny BP 400 (sows) and BP 450 (boars), for experimental conditions, in percentage (\%) and numbers.

\begin{tabular}{|c|c|c|c|}
\hline \multirow{2}{*}{ Progeny } & \multicolumn{3}{|c|}{ Reproductive performance expected } \\
\cline { 2 - 4 } & Parturition (\%) & Return to estrus (\%) & Number of newborn piglets \\
\hline $\begin{array}{c}\text { BP 400 (sows) } \\
\text { and }\end{array}$ & $\geq 80$ & $\leq 20$ & $10-11$ \\
BP 450 (boars) & & & \\
\hline
\end{tabular}

In order to standardize the treated and control groups of inseminated sows, 125 Landrace and Large White cross-bred with similar genetic breeds, progeny BP 400® (table 1), from the same sows and boars production farm and with reproductive cycle between the first and fifth parturition were distributed the among experimental groups.

Sows were housed at the same facility with identical nutritional handling and sanitary conditions.

\subsection{Semen collection, sperm evaluation and dilution}

Sixteen semen collections were made for both boars always in the same day and time, once a week. Semen was standardized through sperm evaluation at the insemination facility as soon as it was collected according to the minimum cut point parameters: $90 \%$ sperm motility, 3 billion sperm cells per $100 \mathrm{~mL}$ bottle of diluted semen and sperm vigor equal to score four [13,14]. Sperm concentration was determined with a numeric scale sperm densimeter. Sperm vigor was numerically quantified using optic microscope, with score zero for dead sperm cells, 1 for low vigor, 2 for medium vigor, 3 for satisfactory and 4 for high [13-14]. Sperm motility was 
also quantified using an optic microscope. In this case, the minimum percentage zero applied to dead sperm cells and the maximum 90 to high motility sperm cells. The semen was diluted in MIII ${ }^{\circledR}$ brand, from Minitub Company. Diluted semen was stored at $18^{\circ} \mathrm{C}$ in $100 \mathrm{~mL}$ plastic bottles. Semen motility and vigor of both treated and control groups were evaluated at the harvesting time just after dilution (time zero).

\subsection{Homeopathic preparations}

Three homeopathic preparations and 1 placebo (inert vehicle), Avena sativa $6 \mathrm{cH}$, Pulsatilla nigricans $6 \mathrm{cH}$, Pulsatilla nigricans $6 \mathrm{cH}$ plus Avena sativa $6 \mathrm{cH}$, were used to compose 3 treated groups and 1 control. Both the homeopathic preparations and the inert vehicle were coded to carry out a blind controlled study; the code was only known by the pharmacy that prepared the tested solutions. All 3 homeopathic preparations and the placebo were prepared as $30 \mathrm{mg}$ saccharine embedded globules, according to the Brazilian Homeopathic Pharmacopeia [15, 16, 17, 18]. The control group received globules not impregnated with active substances. Two globules were diluted per $100 \mathrm{~mL}$ of diluted semen at once. The corresponding codes were recorded on the tube at this moment.

\subsection{Experimental groups and insemination of sowa}

Four groups were constituted: control $(\mathrm{n}=31)$, Avena sativa $(\mathrm{n}=31)$, Pulsatilla nigricans $(\mathrm{n}=32)$ and Avena sativa plus Pulsatilla nigricans $(\mathrm{n}=31)$. Using Suinsoft ${ }^{\circledR}$ software [19], 125 sows with similar reproductive performance were selected and randomly distributed among the treated and control groups. The sows from all the 4 groups were inseminated three times with the same estrous diagnostic procedure.

The first insemination was made when the male tolerance reflex was detected and the following 2 inseminations were carried out at 2 hours intervals. [14]. Suinsoft ${ }^{\circledR}$ [19] software was used to calculate the results in the treated and control groups regarding to the number of female parturitions and return to estrous. Microsoft Excel ${ }^{\circledR}$ software was used for plotting the total number of newborn piglets and the fertility rate.

\subsection{Statistics}

The comparison of parturition rate and return to estrous rate between groups was made through Chi-Square test. To compare the total median number of newborn piglets Kruskal-Wallis test was used [20]. Significance level was 5\%, and all analyses were made with software Minitab ${ }^{\circledR}$ 14.0.

Suinsoft ${ }^{\circledR}$ software [19] was used to calculate the results in the control and treated groups regarding the parturition number and the number of return to estrous; for the total number of newborns and the fertility rate software Microsoft Excel ${ }^{\circledR}$ was used.

\section{Results}

Table 2 shows the results of the parturition numbers and their respective percentages, the number of return to estrous and newborn piglets, for the control and treated groups.

Regarding the parturition rate and the proportion of return to estrous there was significant difference $(\mathrm{p} \leq 0.05)$ between Avena sativa and the other groups: Pulsatilla nigricans; Avena sativa + Pulsatila nigricans and control. There was no significant difference among the groups regarding the total median number of newborn piglets $(\mathrm{p}>0.05)$. There was no statistical significance between any of the groups regarding the parturition percentage.

Table 2 - Reproductive results obtained from data on parturition number, number of return to estrus and their respective percentages (\%) and number of newborn piglets for control and treated 
groups with Avena sativa, Pulsatilla nigricans, Avena sativa plus Pulsatilla nigricans in swine semen.

\begin{tabular}{|l|c|c|c|c|}
\hline \multicolumn{1}{|c|}{ Parameter } & Control & Avena sativa & $\begin{array}{c}\text { Pulsatilla } \\
\text { nigricans }\end{array}$ & $\begin{array}{c}\text { Avena sativa }+ \\
\text { Pulsatila nigricans }\end{array}$ \\
\hline Number of parturitions ** & 22 & 28 & 22 & 19 \\
\hline Parturition percentage (\%)** & $70.96^{\mathrm{b}}$ & $90.32^{\mathrm{a}}$ & $68.75^{\mathrm{b}}$ & $61.29^{\mathrm{b}}$ \\
\hline Numbers of return to estrus** & 9 & 3 & 10 & 12 \\
\hline Return to estrus percentage (\%)** & $29.03^{\mathrm{b}}$ & $9.68^{\mathrm{a}}$ & $31.25^{\mathrm{b}}$ & $38.70^{\mathrm{b}}$ \\
\hline Mean number of newborn piglets* & 10.13 & 10.64 & 11.27 & 11.21 \\
\hline Median number of newborn piglets* & 8.0 & 11.0 & 9.5 & 8.0 \\
\hline
\end{tabular}

Different letters in the same row indicate statistical difference $(P \leq 0.05)$ between groups. ${ }^{*}$ Kruskal-Wallis test; $* * X^{2}$ test.

\section{Discussion}

The semen treated with Avena sativa exhibited the best and significant results regarding to parturition, with the lowest number of sows that returned to estrous after insemination and, consequently, higher fertility rate when compared to Pulsatilla nigricans, Avena sativa + Pulsatilla nigricans and control groups. Pulsatilla nigricans either alone or associated to Avena sativa presented negative effect on the sperm cells resulting in lower parturition rates for the two groups in which it was, although the literature describes this plant as beneficial for the reproductive system of domestic animals [10]. Even though the mean of newborn piglets was higher for the group treated with Avena sativa by comparison to the control and the groups treated with Pulsatilla nigricans or Avena sativa + Pulsatilla no statistical significance was detected. The results obtained for Avena sativa in diluted semen are, thus, encouraging for the purpose of increasing the fecundity rate of swine herd.

Previous studies have shown the beneficial effect of the use of some homeopathic preparations applied directly on sperm cells: Soto et al.[8] obtained similar results using Avena sativa in swine semen. In this case there was $83 \%$ parturition rate, as well as improvement of vigor and sperm motility, even after 24 hours of semen harvesting. Aziz and Enbergs [21] demonstrated that homeopathic treatment of bovine cooled frozen? semen with different dilutions of monoensin ( 5 up to 14 times) resulted in a significant increase of the mitochondrial activity of sperm cells measured by cytometry, even though a negative effect was observed on the semen viability.

Radkumar et al [22], conducted a study to assess the effectiveness of a homeopathic complex (Calcarea phosphorica $30 \mathrm{cH}$, Aletris farinosa $30 \mathrm{cH}$, Pulsatilla $30 \mathrm{cH}$, Aurum muriaticum natronatum $30 \mathrm{cH}$, Sepia $30 \mathrm{cH}$ and Phosphorus $30 \mathrm{cH}$ ) in the treatment of rue anoestrus in cows, being scored as $100 \%$ effective in inducing with no return to estrus; also, a steady increase in the concentration of estradiol was observed in the treated animals, maybe due to the presence of Pulsatilla in the complex $[9,10,11]$.

New researches must be developed with other homeopathic preparations or associations that have a putative ability to improve the parturition rate and the number of newborn piglets at the same time. In this study, Avena sativa showed a specific ability to reduce the number of return to estrous and consequently to improve the parturition rate in experimental conditions; the economic impact of this improvement in a technified herd production seems promising. Supposing the systematic implantation of this technology in a 1000-sow herd, there would be a reduction of 360 inseminations per year, or 2,4 parturitions per year /sow, (2400 total, with this technique) versus 2,04 ( 2040 total, without this technique) [8, 23].

In conclusion, Avena sativa as a homeopathic preparation can be indicated directly in sperm cells in order to improve the parturition rate in technified swine farms. 


\section{References}

[1] Candini PH, Viana CHC, Hoffman ME. Comparação dos índices reprodutivos com inseminação artificial ou cobertura natural sob influências sazonais em suínos. Braz J Vet Ani Sci. 2000; 37: 10-20. [Portuguese].

[2] Pelland C, Cassar G, Kirkwood R. Fertility after intrauterine insemination with conventional or low numbers of spermatozoa in sows with synchronized ovulation. J Swine Health Prod. 2008; 16:188-192.

[3] Diehl, GN, Sobrinho AFW, Kummer R. Nova pipeta para inseminação intra-uterina em suínos. Cien Rur. 2006; 36:179-185. [Portuguese].

[4] R. F. Fitzgerald RF, Jones GF, Stalder KJ. Effects of intrauterine and cervical artificial-insemination catheters on farrowing rate and litter size. J S H Prod. 2008; 16:10-15.

[5] Bortolozzo FP, Wentz I. Incremento da eficiência reprodutiva em programa de inseminação artificial (IA) no suíno. In: Proceedings of the Congresso Brasileiro de Reprodução Animal; Belo Horizonte, Brazil. Belo Horizonte: Colégio Brasileiro de Reprodução Animal; 1995.p.131-141. [Portuguese].

[6] Roner, MNB, Silva Filho JM, Palhares MS. Desenvolvimento de um sistema de resfriamento e conservação de sêmen suíno. Arq Bras Med Vet Zoot. 2006; 58: 78-86. [Portuguese].

[7] Flores LAS, Wentz I, Bortolozzo FP. Comparação entre diferentes métodos de inseminação artificial em suínos. Cienc Rur. 2004; 34: 1169-1175. [Portuguese].

[8] Soto FRM, Vuaden ER, Coelho CP, Bonamin LV, Azevedo SSA, Benites NR. Effect of Avena sativa CH6 in the metabolism of diluted semen of swine. Vet Zoot. 2009; 16: 367-372.

[9] Demarque D, Jouanny J, Poitevin B, Saint-Jean Y. Farmacologia y Matéria Médica Homeopática. vol.1. Madrid (Spain): Boiron; 1997.

[10]. Montano JSR. Pulsatilla and ovulation. Rev Hom. 1981; 151:31-32.

[11] Gerhar I, Wallis E. Individualized homeopathic therapy for male infertility Homeopathy. 2002; 91:133144.

[12] Lobreiro J. Homeopathic treatment for infertility in a prize Nelore bull. Homeopathy. 2007; 96:.49-51.

[13] Johnston SD, Kustritz MVR, Olson PNS. Semen collection, evaluation, and preservation. In: Canine and Feline Theriogenology $1^{\text {st }}$ ed. Philadelphia (USA): W.B. Saunders; 2001. 287-306.

[14] Bortolozzo FP, Irgang I. Inseminação artificial na suinocultura tecnificada. Porto Alegre (Brazil): Genamera Lima Jaques Pinto Editores; 2005. [Portuguese].

[15] Costa RA. Homeopatia Atualizada. Homeopatia Escola Brasileira. Petrópolis (Brazil): Vozes; 1988. [Portuguese].

[16] Farmacopéia Homeopática Brasileira. 2nd ed. São Paulo (Brazil): Atheneu; 1997. [Portuguese].

[17] Fontes OL. Farmácia Homeopática. Teoria e Prática. Barueri (Brazil): Editora Manole: 2001. [Portuguese]. 
[18] Gutierrez MA, Silva MLF, Moreira MCR, Luna RL, Maciel R, Kazuma Y. Manual de Normas Técnicas de Farmácias Homeopáticas. 3rd ed. Gutierrez MA, Silva MLF, Moreira MCR, Luna RL, Maciel R, Kazuma Y editors. São Paulo (Brazil): Associação Brasileira de Farmacêuticos Homeopatas; 2001. [Portuguese].

[19] Programa Suinsoft. Sistemas para suinocultura. Versão $3.0 .7,2005$. http://www.suinsoft.com.br/Internet/PROD/prod_gestao_tec.asp

[20] Zar JH. Biostatistical analysis. 4th ed. Upper Saddle River (USA): Prentice Hall, Pearson; 1999.

[21] Aziz, DM, Enbergs H. Stimulation of bovine sperm mitochondrial activity by homeopathic dilutions of monensin. Homeopathy. 2005; 94:229-232.

[22] Rajkumar, R, Srivastava, SK, Yadav, MC, Varshney, VP, Varshney, JP, Kumar, H. Effect of a Homeopathic complex on oestrus induction and hormonal profile in anoestrus cows. Homeopathy. 2006; 95:131-135.

[23] Soto, FRM, Vuaden, ER, Benites, NR, Azevedo, SS, Pinheiro, SR, Coelho, CP, Vasconcellos, AS. Evaluation of zootecnics indexes of a commercial swine herd using homeopathic treatment. Vet e Zootec. 2008; 15: $577-586$

\title{
Rendimento reprodutivo de suínos inseminados com esperma tratado com medicamento homeopático
}

\begin{abstract}
RESUMO
Objetivos: este estudo buscou avaliar o rendimento reprodutivo de suínos inseminados com esperma tratado com medicamentos homeopáticos. Materiais e métodos: o esperma de dois suínos sexualmente maduros de 18 meses de idade híbridos Pietrain e Duroc, com rendimento genético e reprodutivo similares foi selecionado, assim como 125 fêmeas. Dezesseis amostras de esperma foram coletadas e estandarizadas através de avaliação do esperma. Três preparações homeopáticas e um controle (placebo) foram testados no esperma ( $\mathrm{n}=31 / 32$ por grupo): Avena sativa $6 \mathrm{cH}$, Pulsatilla nigricans $6 \mathrm{cH}$ and Avena sativa $6 \mathrm{cH}+$ Pulsatilla nigricans $6 \mathrm{cH}$. As fêmeas foram inseminadas 3 vezes com os mesmos procedimentos de diagnóstico do estro. Resultados: houve diferença significativa $(\mathrm{p}<0,05)$ entre Avena sativa $6 \mathrm{cH}$ e os outros 3 grupos no retorno ao estro e taxa de partos. Não houve diferença significativa entre os grupos no número de recémnascidos. Conclusão: os dados sugerem que a preparação homeopática Avena sativa pode ser utilizada diretamente nas células espermáticas para melhorar a taxa de partos em fazendas tecnificadas de criação de suínos.

Palavras-chave: suínos; rendimento reprodutivo; esperma; homeopatia; estudo cego controlado
\end{abstract}

\section{Rendimiento reproductivo de porcinos inseminados con esperma tratado com medicamento homeopático}

\author{
RESUMEN
}


Objetivos; este estudio busco evaluar el rendimiento reproductivo de porcinos inseminados com esperma tratado com medicamentos homeopáticos. Materiales y métodos: el esperma de 2 porcinos sexualmente maduros de 18 meses de edad híbridos Pietrain y Duroc, com rendimiento genético y reproductivo similares fue seleccionado, así como 125 hembras. Dieciséis muestras de esperma fueron recogidas y estandarizadas mediante evaluación del esperma. Tres preparados homeopáticos y un control (placebo) fueron testeados en el esperma ( $\mathrm{n}=31 / 32$ por grupo): Avena sativa $6 \mathrm{cH}$, Pulsatilla nigricans $6 \mathrm{cH}$ and Avena sativa $6 \mathrm{cH}+$ Pulsatilla nigricans $6 \mathrm{cH}$. Las hembras fueron inseminadas 3 veces con los mismos procedimientos de diagnóstico del estro. Resultados: hubo diferencia significativa $(\mathrm{p} \leq 0,05)$ para Avena sativa $6 \mathrm{cH}$ en comparación con los demás grupos en el retorno al estro y tasa de partos. No hubo diferencia significativa entre ninguno de los grupos en el número de recién nacidos. Conclusión: estos datos sugieren que el preparado homeopático Avena sativa puede ser directamente utilizado en las células espermáticas para mejorar la tasa de partos en granjas tecnificadas de porcinos.

Palabras llave: porcinos; rendimiento reproductivo; esperma; homeopatía; estudio ciego controlado

\section{(c)) BY-No-ND Licensed to GIRI}

Support: authors declare that this study received no funding

Conflict of interest: authors declare there is no conflict of interest

Received: 23 February 2010; Revised: 12 March 2010; Published: 31 March 2010.

Correspondence author: Francisco Rafael Martins Soto, chicosoto34@gmail.com

How to cite this article: Soto FRM, Vuaden ER, Coelho CP, Bonamin LV, Azevedo SS, Benites NR, Visintin JA, Barros FRO, Goissis MD, Assumpção MEODA, Marques MG. Reproductive performance of sows inseminated with diluted semen treated with homeopathic medicine. Int J High Dilution Res [online]. 2010 [cited YYYY Month dd]; 9(30): 51-57. Available from: http://www.feg.unesp.br/ ojs/index.php/ijhdr/article/view/375/413 